\title{
Type studies on Coprinus dunarum Stoll
}

\author{
Irja Saar ${ }^{1}$, Kuulo Kalamees ${ }^{1,2} \&$ Edgars Vimba $^{3}$ \\ ${ }^{1}$ Institute of Ecology and Earth Sciences, University of Tartu, Ravila St. 14A, 50411 Tartu, Estonia. \\ E-mail: irja.saar@ut.ee \\ ${ }^{2}$ Institute of Agricultural and Environmental Sciences, Estonian University of Life Sciences, Kreutzwaldi St. 5D, \\ 51014 Tartu, Estonia. E-mail: kuulo.kalamees@ut.ee \\ ${ }^{3}$ Department of Botany and Ecology, University of Latvia, Kronvalda bulv. 4, LV-1586 Rìga, Latvia. \\ E-mail: evimba@lanet.lv
}

\begin{abstract}
The study of the type specimens from Coprinus dunarum revealed that according to ITS sequences these specimens belong to the species Coprinopsis atramentaria. Thus, $C$. dunarum should be treated as a synonym of the latter.
\end{abstract}

Keywords: lectotype, neotype, sand dune fungus

\section{INTRODUCTION}

Ferdinand Erdmann Stoll found Coprinus specimens from the dunes of the Baltic Sea in Riga, Latvia, and described a new species C. dunarum (Stoll, 1929, 1930), without presenting any specific diagnostic characters (except the habitat on dunes). Afterwards, this species was collected from dunes in Lithuania (Urbonas, 1981), but it was stated being rare in both countries (Urbonas et al., 1986). Stoll's species remained rather unknown among international mycological crowd, and only one collection from Germany has been reported (Bresinsky, 2007).

Urbonas (1981) selected a neotype from Lithuanian collections, because the location of the Stoll's original specimen was not known and only the aquarelle was deposited in the herbarium of the University of Latvia. Bresinsky (2007) reported the presence of Stoll's specimen in the Romell's collection at the Swedish Museum of Natural History, designated it as a lectotype and presented detailed historic background of this specimen and species.

Hopple \& Vilgalys (1999) demonstrated polyphyletic origin of the genus Coprinus Pers. based on rDNA phylogeny. Afterwards, Redhead et al. (2001) split the genus Coprinus into four genera, preserving the generic name Coprinus to a small group around the type species $C$. comatus (O.F. Müll.) Pers. According to the phylogenetic studies, Coprinus sensu stricto belongs to the Agaricaceae (Moncalvo et al., 2002; Vellinga, 2004) and the other genera (Coprinellus P. Karst., Coprinopsis P. Karst., and Parasola Red- head, Vilgalys \& Hopple) to the Psathyrellaceae (Moncalvo et al., 2002; Vasutova et al., 2008; Padamsee et al., 2008). The phylogenetic taxonomy of these genera in the Psathyrellaceae is rather well investigated (Padamsee et al., 2008; Nagy et al., 2009, 2010, 2012, 2013a, 2013b) simplifying the aim of this study to resolve the taxonomic placement of Coprinus dunarum.

\section{MATERIALS AND METHODS}

The microscopic investigations were carried out using a Nikon Eclipse 80i light microscope at magnification $x 1000$. The measurements were made in $3 \% \mathrm{KOH}$ solution. The spore measurements are based on 25 randomly taken basidiospores from each specimen.

The abbreviations of fungaria are used according to the Index Herbariorum (Thiers, 2015).

\section{Studied specimens}

Coprinopsis acuminata (Romagn.) Redhead, Vilgalys \& Moncalvo

Estonia, Tartu Co., Meeksi, Järvselja, on forest path, 25.08.2011, leg./ det. V. Liiv (TU 118370).

Coprinopsis atramentaria (Bull.) Redhead, Vilgalys \& Moncalvo

Estonia, Hiiu Co., Pühalepa Comm., Suuremõisa, in manor park, 5.09.2008, leg./ det. V. Liiv (TU 106403); Saare Co., Muhu Comm., Koguva, in yard, 15.09.2012, leg./ det. V. Liiv (TU 118611).

Coprinopsis romagnesiana (Singer) Redhead, Vilgalys \& Moncalvo

Estonia, Lääne Co., Lihula Comm., Penijõe park, Matsalu National Park, 9.09.2006, leg./ det. K. Kalamees 
(TAAM 177570, as C. cf. atramentaria); Põlva Co., Kõlleste Comm., Kõrista, in mixed forest, 29.08.2011, leg./ det. V. Liiv (TU 118257).

Coprinus comatus (O.F. Müll.) Gray

Latvia, Cesis Municipality, Ciruli, Gauja National Park, 20.09.2005, leg./ det. K. Kalamees (TAAM 177304, as C. dunarum).

Coprinus dunarum Stoll, Zeitschrift für Pilzkunde II 8(6): 81.

Latvia, Riga, Wanderdüne am Riga-Strand, 1.07.1926, leg. F.E. Stoll (S F58633, lectotype).

Lithuania, Kretinga Co., near Palanga, on sand, between organic litter, 22.09.1977, leg./ det. V. Urbonas (BILAS 14392, neotype).

Estonia, Saare Co., Kaarma Comm., Mändjala, on dunes, grey coastal dune subtype, 4.09.1998, leg./ det. K. Jürgens (TAAM 172597). Germany, Niedersachsen, Insel Wangerooge, Ostteil, Weißdüne, im nackten Sand fruchtend, unweit Ammophila, 22.10.1990, leg./ det. A. Bresinsky (M 0223078, as C. cf. dunarum). Latvia, Riga District, Mangal̦sala, among Vecāksi and the estuary of Daugava river, on dunes, 10.2000, leg. A. Liepins, det. E. Vimba (RIG F1 8724, as C. sp.); Carnikava Municipality, Lilaste, on foredune, on rotting Salix, 29.09.2001, leg./ det. A. Opmanis (RIG Fl 8723, as C. sp.); Jurmala, Lielupe, on the bank of river Lielupe, among Salix, 27.09.2001, leg. A. Opmanis, det. Inita Daniele (the Natural History Museum of Latvia, LDM F3891).

\section{Molecular methods}

The genomic DNA was extracted with a lysis procedure in $10 \mathrm{x}$ reaction buffer $\mathrm{B}(0.8 \mathrm{M}$ Tris$\mathrm{HCl}, 0.2 \mathrm{M}\left(\mathrm{NH}_{4}\right)_{2} \mathrm{SO}_{4}, 0.2 \% \mathrm{w} / \mathrm{v}$ Tween-20; Solis Biodyne, Tartu, Estonia), including Proteinase $\mathrm{K}(0.5 \mathrm{mg} / \mathrm{ml}$; Thermo Fisher Scientific Inc., Waltham, MA USA) and incubated at $56^{\circ} \mathrm{C}$ for overnight. The High pure PCR template preparation kit (Roche Applied Science, Mannheim, Germany) was used for the type specimens, following the protocol of the manufacturer. The PCR amplification was performed with the primers ITSOFt (5'-acttggtcatttagaggaagt-3') - LB-W (5'-cttttcatctttccctcacgg-3') or ITSOFt - ITS4 (5'-tcctccgcttattgatatgc-3') for ITS region, using HOT FIREPol @ Blend Master Mix Ready to Load (10 mM $\mathrm{MgCl}_{2}$; Solis BioDyne, Tartu, Estonia) or puReTaq Ready-To-GoTM PCR Beads (GE Healthcare, Freiburg, Germany) with $0.4 \mu \mathrm{M}$ of each primer and $5 \mu 1$ of DNA solution, following the protocols of the manufacturers. The DNA of the type specimens was amplified in two shorter parts using primer pairs ITSOFt - ITS2 (5'-gctgcgttcttcatcgatgc-3') and 58SF (5'-atgcatcgatgaagaacgc-3') - ITS4. The PCR amplification program was as follows: an initial denaturation at $95{ }^{\circ} \mathrm{C}$ for $15 \mathrm{~min}$, followed by 35 cycles at $95^{\circ} \mathrm{C}$ for $30 \mathrm{sec}$, at $55^{\circ} \mathrm{C}$ for $30 \mathrm{sec}$, at $72{ }^{\circ} \mathrm{C}$ for $1 \mathrm{~min}$ and a final extension at $72{ }^{\circ} \mathrm{C}$ for $10 \mathrm{~min}$. The PCR products were purified enzymatically (10 u Exonuclease I - 1 u FastAP TM Thermosensitive Alkaline Phosphatase; Thermo Fisher Scientific Inc., Waltham, MA USA), according to the manufacturer's instructions. The sequences were performed by Macrogen Inc. (Seoul, Korea) using primers ITS5 (5'-ggaagtaaaagtcgtaacaagg-3') and ITS4.

The sequences were inspected and assembled using Sequencher 4 software (Gene Codes, Ann Arbor, USA). The DNA sequences (Table 1) were uploaded into PlutoF cloud database (Abarenkov et al., 2010b), including the collection data, which partly are reachable through public web output UNITE (http//unite.ut.ee; Abarenkov et al., 2010a).

Additionally, the sequences of Atramentarii clade (Nagy et al., 2013a) from Genebank were added into data matrix (Tabel 1). Coprinopsis lagopus (Fr.) Redhead, Vilgalys \& Moncalvo lineage was served as outgroup as closest to Atramentarii clade (Padamsee et al., 2008; Nagy et al., 2013a, b).

\section{Phylogenetic analyses}

The alignments were performed using L-INSi strategy as implemented in MAFFT v7.215 (Katoh \& Standley, 2013). Minor manual adjustments were performed with Se-Al 2.0a11 (Rambaut, 1996).

The Maximum parsimony (MP) analyses were conducted in PAUP* 4.0b10 (Swofford, 2002) using 1000 heuristic searches with random taxon addition sequences, TBR branch swapping, Maxtrees set to 10,000 , the restriction to save 100 trees in each replicate applied, followed by additional swapping of the resulting trees. The confidence of branching was assessed using bootstrap re-sampling (bs): 1000 replicates, each with 10 random taxon addition sequences and MulTrees off. All the characters were treated as unordered, equally weighted, treating gaps as missing data.

Bayesian inference of phylogeny was performed with MrBayes 3.1.2 (Ronquist et al., 2012) applying GTR + G DNA substitution model chosen by AIK information criterion in program MrModeltest 2.2 (Nylander, 2004). The Markov chains 
Table 1. Specimens used in the study: collection data, spore measurements, and codes for ITS sequences in databases (sequences generated for this study are shown in boldface). * LDM - The Natural History Museum of Latvia, Riga.

\begin{tabular}{|c|c|c|c|c|}
\hline Species & Country & $\begin{array}{l}\text { Collection and/or } \\
\text { fungarium }\end{array}$ & $\begin{array}{l}\text { Length and width of spores } \\
(\mu \mathrm{m}) ; \text { their ratio Q (length/ } \\
\text { width) }\end{array}$ & $\begin{array}{l}\text { UNITE or } \\
\text { GenBank code }\end{array}$ \\
\hline Coprinopsis acuminata (Romagn.) & Estonia & TU 118370 & $8.4-9.9 \times 4.6-5.8 ; 1.6-2.0$ & UDB015511 \\
\hline \multirow{2}{*}{ Redhead, Vilgalys \& Moncalvo } & Norway & SZMC-NL-0958 & & JX118698 \\
\hline & Slovakia & SZMC-NL-3028 & & HQ847046 \\
\hline $\begin{array}{l}\text { Coprinopsis ammophilae (Courtec.) } \\
\text { Redhead, Vilgalys \& Moncalvo }\end{array}$ & Unspecified & WAT 24982 & & HQ847008 \\
\hline \multirow{2}{*}{$\begin{array}{l}\text { Coprinopsis atramentaria (Bull.) Redhead, } \\
\text { Vilgalys \& Moncalvo }\end{array}$} & Estonia & TU 106403 & $8.5-10.6 \times 5.2-6.4 ; 1.5-1.8$ & UDB011751 \\
\hline & Estonia & TU 118611 & $8.4-10.2 \times 4.8-6.1 ; 1.6-2.0$ & UDB018016 \\
\hline (as Coprinus dunarum) & Estonia & TAAM 172597 & $7.6-9.4 \times 4.9-6.6 ; 1.4-1.8$ & UDB011134 \\
\hline (as Coprinus dunarum) & Latvia & S F58633, lectotype & $8.0-9.8 \times 5.0-6.4 ; 1.4-1.7$ & UDB011869 \\
\hline (as Coprinus sp.) & Latvia & RIG Fl 8723 & $9.4-11.3 \times 5.4-6.7 ; 1.5-1.9$ & UDB022732 \\
\hline (as Coprinus sp.) & Latvia & RIG Fl 8724 & $9.7-11.6 \times 5.9-7.0 ; 1.5-1.8$ & UDB015940 \\
\hline (as Coprinus dunarum) & Latvia & LDM F $3891 *$ & $8.2-10.4 \times 6.4-7.4 ; 1.3-1.5$ & UDB022733 \\
\hline \multirow{2}{*}{ (as Coprinus dunarum) } & Lithuania & BILAS 14392 , neotype & $6.2-8.2 \times 4.8-6.0 ; 1.2-1.5$ & UDB011870 \\
\hline & Unspecified & SZMC-NL-3399 & & FN396110 \\
\hline Coprinopsis atramentaria var. squamosa & Hungary & SZMC-NL-2148 & & FM878014 \\
\hline $\begin{array}{l}\text { Coprinopsis calospora (Bas \& Uljé) } \\
\text { Redhead, Vilgalys \& Moncalvo }\end{array}$ & The Netherlands & Bas 8795a, holotype & & JX118675 \\
\hline \multirow{2}{*}{$\begin{array}{l}\text { Coprinopsis cinerea (Schaeff.) Redhead, } \\
\text { Vilgalys \& Moncalvo }\end{array}$} & Estonia & TU 118308 & & UDB015474 \\
\hline & The Netherlands & Uljé 1060 & & JX118676 \\
\hline \multirow{2}{*}{$\begin{array}{l}\text { Coprinopsis erythrocephala (Lév.) Redhead, } \\
\text { Vilgalys \& Moncalvo }\end{array}$} & Hungary & SZMC-NL-1701 & & JX118703 \\
\hline & The Netherlands & Crispijn 071-41 & & JX118704 \\
\hline \multirow[t]{2}{*}{$\begin{array}{l}\text { Coprinopsis fusispora L. Nagy, Vágvölgyi } \\
\& \text { Papp }\end{array}$} & Hungary & $\begin{array}{l}\text { SZMC-NL-1227, } \\
\text { holotype }\end{array}$ & & JX118740 \\
\hline & Hungary & SZMC-NL-3863 & & JX118742 \\
\hline \multirow{2}{*}{$\begin{array}{l}\text { Coprinopsis geesterani (Uljé) Redhead, } \\
\text { Vilgalys \& Moncalvo }\end{array}$} & The Netherlands & Uljé 1078, holotype & & JQ118699 \\
\hline & Hungary & SZMC-NL-3844 & & HQ847047 \\
\hline \multirow{2}{*}{$\begin{array}{l}\text { Coprinopsis insignis (Peck) Redhead, } \\
\text { Vilgalys \& Moncalvo }\end{array}$} & Estonia & TU 118725 & & UDB019628 \\
\hline & Hungary & SZMC-NL-1510 & & JX118738 \\
\hline $\begin{array}{l}\text { Coprinopsis jonesii (Peck) Redhead, } \\
\text { Vilgalys \& Moncalvo }\end{array}$ & Estonia & TU 106885 & $8.2-9.6 \times 6.6-7.5 ; 1.2-1.4$ & UDB015198 \\
\hline \multirow[t]{2}{*}{ (as Coprinus cf. dunarum) } & Germany & M 0223078 & $7.1-9.2 \times 6.3-7.4 ; 1.1-1.4$ & UDB019664 \\
\hline & Hungary & SZMC-NL-0777 (BP) & & FN396116 \\
\hline \multirow{2}{*}{$\begin{array}{l}\text { Coprinopsis krieglsteineri (Bender) } \\
\text { Redhead, Vilgalys \& Moncalvo }\end{array}$} & Hungary & SZMC-NL-2345 & & FM878019 \\
\hline & Hungary & SZMC-NL-3413 & & JX118701 \\
\hline \multirow{2}{*}{$\begin{array}{l}\text { Coprinopsis lagopus (Fr.) Redhead, Vilgalys } \\
\& \text { Moncalvo }\end{array}$} & Hungary & SZMC-NL-3861 & & JX118706 \\
\hline & Hungary & SZMC-NL-1558 & & JX118711 \\
\hline \multirow{2}{*}{$\begin{array}{l}\text { Coprinopsis ochraceolanata (Bas) Redhead, } \\
\text { Vilgalys \& Moncalvo }\end{array}$} & Hungary & SZMC-NL-0192 & & JX118697 \\
\hline & The Netherlands & Unspecified & & HQ847051 \\
\hline $\begin{array}{l}\text { Coprinopsis romagnesiana (Singer) } \\
\text { Redhead, Vilgalys \& Moncalvo }\end{array}$ & Estonia & TU 118257 & $9.4-11.0 \times 4.8-6.6 ; 1.6-2.0$ & UDB015430 \\
\hline \multirow{3}{*}{$\begin{array}{l}\text { Kedhead, vilgalys } \alpha \text { Mioncalvo } \\
\text { (as C. atramentaria) }\end{array}$} & Estonia & TAAM 177570 & $8.6-10.8 \times 5.3-6.3 ; 1.5-1.9$ & UDB019487 \\
\hline & Unspecified & AFTOL-ID 1496 & & DQ486694 \\
\hline & USA & PBM992 (WTU) & & FJ168569 \\
\hline Coprinus comatus (as Coprinus dunarum) & Latvia & TAAM 177304 & $9.6-13.5 \times 6.1-8.5 ; 1.4-1.6$ & UDB011133 \\
\hline
\end{tabular}


Monte Carlo (MCMC) were run with $1 \mathrm{M}$ generations and with default values for other prior settings. According to the specified generations the first $100 \mathrm{~K}$ generations without reaching a stable likelihood score were discarded, leaving 18,002 trees for computing the consensus trees and Bayesian posterior probability (pp) values. Tracer ver. 1.6 (Rambaut et al., 2014) was used for summarizing the results of Bayesian phylogenetic analyses.

\section{RESULTS AND DISCUSSION}

The ITS dataset comprises 38 specimens representing 14 Coprinopsis species, and has an aligned length of 660 characters, with 478 constant, 22 parsimony-uninformative, and 160 parsimony-informative characters. Parsimony analysis resulted in 189 equally most parsimonious trees (length $=377, \mathrm{CI}=0.666, \mathrm{RI}=0.895$ ), from which the best tree $(-\ln \mathrm{L}=2948.22758)$ was depicted as a phylogram (Figure 1).

A blastn comparison with the obtained sequences and the sequences in the public sequence databases (NCBI, UNITE) revealed that the ITS sequences of Coprinus dunarum specimens, including lecto- and neotypes, were identical to the sequences of Coprinopsis atramentaria (Figure 1). The specimen from Germany identified as Coprinus agg. dunarum (Bresinsky, 2007) belongs to the species Coprinopsis jonesii (Peck) Redhead, Vilgalys \& Moncalvo.

According to the identity of the ITS region, Coprinus dunarum should be treated as a synonym of Coprinopsis atramentaria. The lack of differences in the macro- and micro-morphological characters confirms conspecificity of these taxa. Pileus of both taxa has been described as greyish white to greyish or yellowish brown, at first ovoid or spherical, then bell-shaped to expanded, covered with disappearing scales. Lamellae are very crowded. Stipe with thickened annular zone from veil remnants at the base, base often rooting up to $5-10 \mathrm{~cm}$.

Basidiospores ellipsoid, 7.5-11 × 5-7 $\mu \mathrm{m}$, germ pore central and truncate. The only distinguishing feature is a different habitat; all specimens determined as $C$. dunarum were collected from sand dunes, growing on organic remains: on wood or on plant debris (Ammophila arenaria, Anthyllis vulneraria, Elymus arenarius). The specimens of Coprinopsis atramentaria grow in mineral soils, in anthropogenic habitats (gardens, parks, grasslands etc.), on wood remains that could be buried in the ground (Ludwig, 2007; Orton \& Watling, 1979; Stoll, 1930; Urbonas, 1981; Vesterholt, 2012).

\section{ACKNOWLEDGEMENTS}

The authors are indebted to the directors and the curators of the fungaria BILAS, LDM, M, RIG, $\mathrm{S}$, TAAM and TU for the loan of the specimens. This work was supported by the institutional research funding IUT20-30 of the Estonian Ministry of Education and Research.

\section{REFERENCES}

Abarenkov, K., Nilsson, R. H., Larsson, K.-H., Alexander, I. J., Eberhardt, U., Erland, S., Høiland, K., Kjøller, R., Larsson, E., Pennanen, T., Sen, R., Taylor, A. F. S., Tedersoo, T., Ursing, B. M., Vrålstad, T., Liimatainen, K., Peintner, U. \& Kõljalg, U. 2010a. The UNITE database for molecular identification of fungi - recent updates and future perspectives. New Phytologist 186: 281-285. http:/ / dx.doi.org/10.1111/j.1469-8137.2009.03160.x

Abarenkov, K., Tedersoo, L., Nilsson, R. H., Vellak, K., Saar, I., Veldre, V., Parmasto, E., Prous, M., Aan, A., Ots, M., Kurina, O., Ostonen, I., Jõgeva, J., Halapuu, S., Põldmaa, K., Toots, M., Truu, J., Larsson, K.-H. \& Kõljalg, U. 2010b. PlutoF - a Web Based Workbench for Ecological and Taxonomic Research, with an Online Implementation for Fungal ITS Sequences. Evolutionary Bioinformatics 6: 189-196.

Bresinsky, A. 2007. Eine fast vergessene Tintlingsart der Weißdünen - Coprinus dunarum Stoll. Zeitschrift für Mykologie 73(1): 95-104.

Dāniele, I., Meiere, D. \& Vimba, E. 2001. Latvijas sēnes F.E. Štolla akvarel̦i. Lettlands Pilze Pilzakvarelle von F.E. Stoll. Latvian Nature Museum, Riga. In Latvian/ Germany. Pictures are available at: http://miko.ldm.gov.lv/Stolla_akvareli.htm

Hopple, J. S. \& Vilgalys, R. 1999. Phylogenetic relationships in the mushroom genus Coprinus and dark-spored allies based on sequence data from the nuclear gene coding for the large ribosomal subunit RNA: Divergent domains, outgroups, and monophyly. Molecular Phylogenetics and Evolution 13(1): 1-19. http://dx.doi.org/10.1006/ mpev. 1999.0634

Katoh, K. \& Standley, D. M. 2013. MAFFT multiple sequence alignment software version 7 : improvements in performance and usability. Molecular Biology and Evolution 30(4): 722-780. http:// dx.doi.org/10.1093/molbev/mst010 


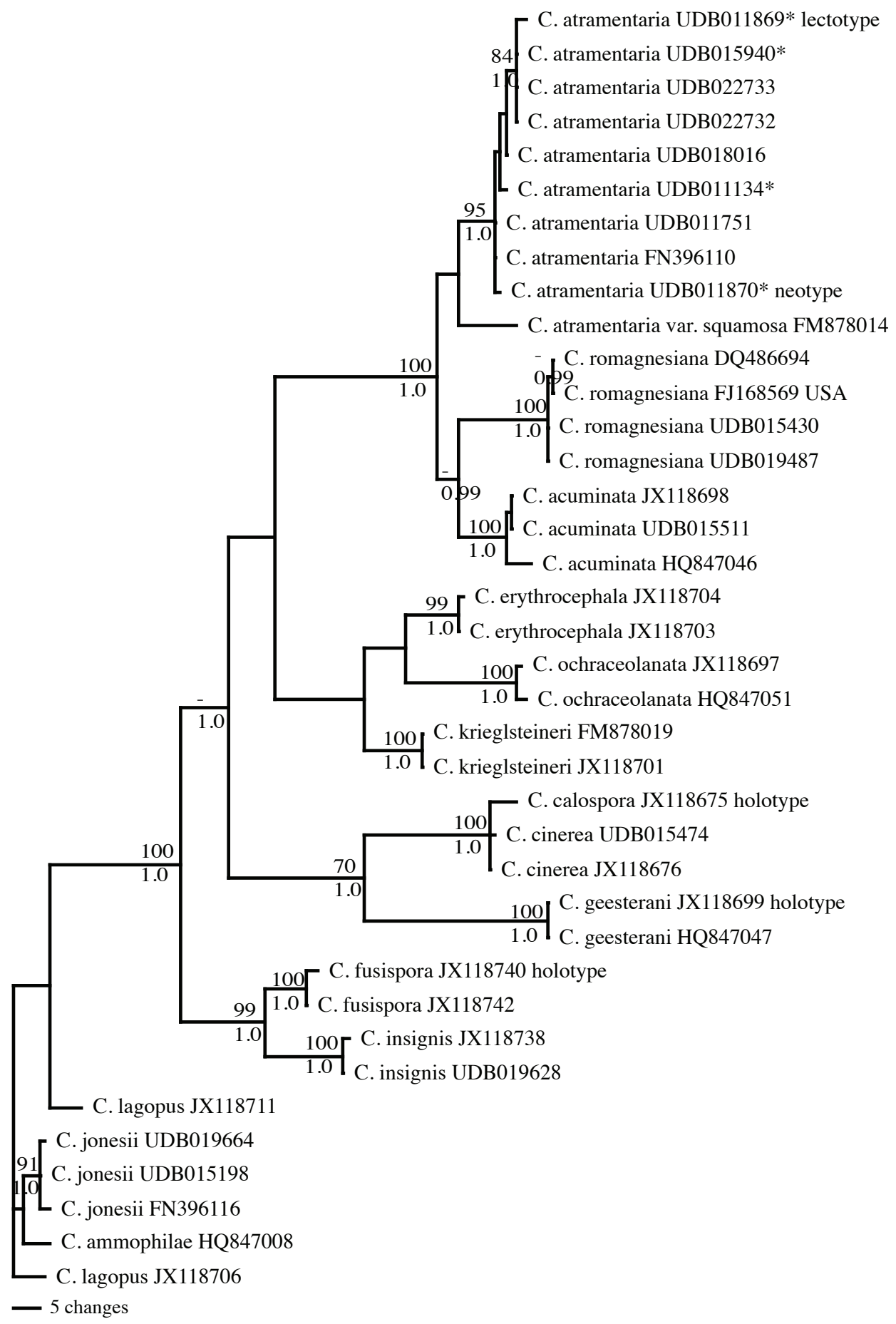

Fig. 1. The phylogeny of ITS sequence data for Coprinopsis atramentaria group inferred by MP analysis. The bootstrap support $(\geq 70 \%)$ and the posterior probabilities $(\geq 95 \%)$ are shown above and below the branches (bs/pp), respectively. The specimens earlier determined as Coprinus dunarum are marked with asterisks (*); C. = Coprinopsis. 
Ludwig, L. 2007. Pilzkompendium 2, Beschreibungen. Fungicon-Verlag, Berlin. 723 pp.

Moncalvo, J. M., Vilgalys, R., Redhead, S. A., Johnson, J. E., James, T. Y., Aime, C. M., Hofstetter, V., Verduin, S. J., Larsson, E., Baroni, T.J., Thorn G. R., Jacobsson S., Clémençon, H. \& Miller, O. K. Jr. 2002. One hundred and seventeen clades of euagarics. Molecular Phylogenetics and Evolution 23: 357-400. http://dx.doi.org/10.1016/ S1055-7903(02)00027-1

Nagy, L. G., Kocsubé, S., Papp, T. \& Vágvölgyi, C. 2009. Phylogeny and character evolution of the coprinoid mushroom genus Parasola as inferred from LSU and ITS nrDNA sequence data. Persoonia 22: 28-37. http://dx.doi. org/10.3767/003158509X422434

Nagy, L. G., Urban, A., Örstadius, L., Papp, T., Larsson, E. \& Vagvolgyi, C. 2010. The evolution of autodigestion in the mushroom family Psathyrellaceae (Agaricales) inferred from Maximum Likelihood and Bayesian methods. Molecular Phylogenetics and Evolution 57: 1037-1048. http:/ / dx.doi.org/10.1016/j.ympev.2010.08.022

Nagy, L. G., Hazi, J., Vagvolgyi, C. \& Papp, T. 2012. Phylogeny and species delimitation in the genus Coprinellus with special emphasis on the haired species. Mycologia 104(1): 254-275. http:// dx.doi.org/10.3852/11-149

Nagy, L. G., Desjardin, D. E., Vagvoelgyi, C., Kemp, R. \& Papp, T. 2013a. Phylogenetic analyses of Coprinopsis sections Lanatuli and Atramentarii identify multiple species within morphologically defined taxa. Mycologia 105(1): 112-124. http:/ / dx.doi.org/10.3852/12-136

Nagy, L. G., Vagvoelgyi, C. \& Papp, T. 2013b. Morphological characterization of clades of the Psathyrellaceae (Agaricales) inferred from a multigene phylogeny. Mycological Progress 12(3): 505-517. http:/ / dx.doi.org/10.1007/s11557-012-0857-3

Nylander, J. A. A. 2004. MrModeltest v2. Program distributed by the author. Evolutionary Biology Centre, Uppsala University.

Orton, P. D. \& Watling, R. 1979. Coprinaceae Part 1: Coprinus. British Fungus Flora Agarics and Boleti 2. Royal Botanic Garden, Edinburgh. 149 pp.

Padamsee, M., Matheny, P. B., Dentinger B. T. M. \& McLaughlin, D. J. 2008. The mushroom family Psathyrellaceae: Evidence for large-scale polyphyly of the genus Psathyrella. Molecular Phylogenetics and Evolution 46(2): 415-429. http:// dx.doi.org/10.1016/j.ympev.2007.11.004
Rambaut, A. 1996. Se-Al: Sequence Alignment Editor. Available from http:/ / tree.bio.ed.ac.uk/software/ Rambaut, A., Suchard, M. A., Xie, D. \& Drummond, A. J. 2014. Tracer v1.6. Available from http:// beast.bio.ed.ac.uk/Tracer

Redhead, S. A., Vilgalys, R., Moncalvo, J. M., Johnson, J. \& Hopple, J. S., 2001. Coprinus Pers. and the disposition of Coprinus species sensu lato. Taxon 50: 203-241. http://dx.doi. org/ $10.2307 / 1224525$

Ronquist, F., Teslenko, M., van der Mark, P., Ayres, D.L., Darling, A., Höhna, S., Larget, B., Liu, L., Suchard, M.A. \& Huelsenbeck, J. P. 2012. MrBayes 3.2: efficient Bayesian phylogenetic inference and model choice across a large model space. Systematic Biology 61(3): 539-542. http:// dx.doi.org/10.1093/sysbio/sys029

Stoll, F. E. 1929. Ein neuer Tintenpilz. Zeitschrift für Pilzkunde II 8(6): 81-82.

Stoll, F. E. 1930. Ein neuer Tintenpilz. Korrespondenzblatt des Naturforscher Vereins zu Riga 60: $144-145$.

Swofford, D. L. 2002. PAUP*. Phylogenetic Analysis Using Parsimony (*and Other Methods). Version 4 beta 10. Sinauer Associates, Sunderland, Massachusetts.

Thiers, B. 2015. (continuously updated) Index Herbariorum: A global directory of public herbaria and associated staff, New York Botanical Garden's Virtual Herbarium. http: / sweetgum.nybg.org/ih/

Urbonas, V. 1981. Species Coprini (Fr.) S.F. Gray rara et minus cognita. Novitates systematicae plantarum non-vascularum 18: 130-132.

Urbonas, V., Kalamees, K. \& Lukin, V. 1986. Conspectus florum agaricalium fungorum (Agaricales s.l.) Lithuaniae, Latviae et Estoniae. Vilnius. 137 pp.

Vasutova, M., Antonin, V. \& Urban, A. 2008. Phylogenetic studies in Psathyrella focusing on sections Pennatae and Spadiceae - new evidence for the paraphyly of the genus. Mycological Reserach 112: 1153-1164. http://dx.doi.org/10.1016/j. mycres.2008.04.005

Vellinga, E. C. 2004. Genera in the family Agaricaceae: evidence from nrITS and nrLSU sequences. Mycological Research 108(4): 354-377. http://dx.doi. org/ 10.1017/S0953756204009700

Vesterholt, J. 2012. Coprinopsis P. Karst. In: Knudsen, H. \& Vesterholt, J. (eds). Funga Nordica. Agaricoid, boletoid, clavarioid, cyphelloid and gastroid genera. 2nd edition. Nordsvamp, Copenhagen: 672-687. 